\title{
Passage of the bracken fern carcinogen ptaquiloside into bovine milk
}

\author{
ME Alonso-Amelot, U Gastillo, F De Jongh \\ Laboratorio de Química Ecológica, Departamento de Química, Facultad de Ciencias, \\ Universidad de Los Andes, Mérida 5101, Venezuela
}

(Received 9 October 1992; accepted 19 March 1993)

\begin{abstract}
Summary - Ptaquiloside has been discovered for the first time in milk samples of a bovine fed a dietary complement ( $6 \mathrm{~kg}$ fresh weight/day) of freshly-cut bracken fronds. This was equivalent to ca $216 \mathrm{mg} /$ day pure ptaquiloside. The compound was found in a quantity of $\mathrm{no}$ less than $0.11 \mathrm{mg} / \mathrm{l}$ in milk. This was determined by the appearance of pterosin $\mathrm{B}-$ the decomposition product of ptaquiloside - in prepurified milk samples treated with mild alkali (pH 8.0 and 11.5). The lack of base treatment led to the absence of pterosin B. A milk prepurification protocol based on methanol-acetonitrile precipitations in succession, hexane and dichloromethane extractions, alkaline treatment, reextraction and silica gel microcolumn chromatography followed by reverse-phase HPLC was developed for the detection of ptaquiloside.
\end{abstract}

bracken / Pterldlum aquilinum / milk / ptaquiloside / human cancer / HPLC

Résumé - Passage du carcinogène ptaquiloside de la fougère Bracken dans le lait de vache. Le ptaquiloside fut découvert pour la première fois dans le lait de bovins dont l'alimentation avait été supplémentée avec des frondes de fougère fraîchement coupées $(6 \mathrm{~kg}$ de matériel frais par jour). Cette quantité équivaut à $216 \mathrm{mg} / j o u r$ de ptaquiloside pur. Pas moins de $0,11 \mathrm{mg} / \mathrm{l}$ de ce composé a été détecté dans le lait. Cette détermination a été réalisée en mesurant la ptérosine $B$ produite par la décomposition du ptaquiloside après traitement du lait prépurifié en milieu légèrement basique $(\mathrm{pH}$ 8,0 et 11,5). En l'absence de traitement alcalin, aucune production de ptérosine $B$ n'a été observée. Afin de détecter le ptaquiloside, nous avons développé un protocole de prépurification du lait basé sur des précipitations successives au méthanol-acétonitrile, extractions à l'hexane et au dichlorométhane, traitement alcalin, réextraction et chromatographie sur microcolonne de gel de silice, le tout suivi par l'analyse par HPLC en phase inverse.

fougère / Pteridium aquilinum / lait / ptaquiloside / cancer humain / HPLC 


\section{INTRODUCTION}

Bracken fern Pteridium aquilinum is considered 1 of the 5 most successful organisms of the plant kingdom (Page, 1976, 1982; Harper, 1977; Fletcher and Kirkwood, 1979). It grows on every continent and at every latitude except for the polar ice-caps (Tryon, 1941), with an extensive coverage of agricultural land (Fenwick, 1988). The widespread clearance of forests in the tropics by ranchers and mine prospectors is rapidly expanding the encroachment of bracken on hillsides, mountain grasslands and cool Andean valleys of the formerly bracken-free pastureland (Gliessman, 1978; Ortega, 1990).

In addition, the range of chemicals with biological impact in this fern is of major economic importance. In addition to the cyanogenic glycosides and tannins (Cooper-Driver and Swain, 1976) and the cytotoxin 1-indanone derivatives pterosins- (fig 1) (Saito et al, 1975), there is the pro-histaminic activity and mutagenicity of braxin 1A (Saito et al, 1990), and the thiamine-destroying compounds dactilifric acid (Fukuoka, 1982) and thiaminase (Evans, 1976; McCleary and Chick, 1977) which cause coordination disorders and death in horses and mules (Diniz et al, 1984). Still other compounds appear associated with damage to the bone-marrow tissue (Evans, 1986), severe leucopenia, thrombocytopenia (Philp and Gowdey, 1967), excess oral mucus breathing difficulty and death in cattle (Evans, 1976), bright blindness in sheep (Barnett and Watson, 1970), heart failure in pigs (Evans et al, 1972; Harding, 1972), and bovine enzootic hematuria (Rosenberger, 1971), a chronic condition of the urinary tract that invariably leads to death. The combination of its wide-spread growth and aggressive chemistry makes bracken a most severe problem for the animal farming industry.
Of major concern is the possible link between bracken infestation and the appearance of esophageal and stomach cancer in individuals living in these areas. This situation was first proposed by Evans et al (1971), then reported in Costa Rica (Villalobos-Salazar, 1985, 1987; VillalobosSalazar et al, 1989a), and suggested for some areas of Wales (Galpin and Smith, 1986) and the Andean states of western Venezuela (Alonso-Amelot and Castillo, unpublished observations). The actual mechanism of this connection has never been established since bracken is not considered, apart from rare occasions, as being suitable for human consumption (Hodge, 1973). However, there is sufficient evidence to believe that milk may provide that link. On the one hand, bracken contains ptaquiloside, a glucoside norsesquiterpene (Van Der Hoeven et al, 1983; Niwa et al, 1983) (see fig 1) of strong carcinogenic potential (Hirono et al, 1987). Once separated from the glucose, the ptaquiloside aglycone becomes a potent electrophilic cyclopropane dienone that reacts strongly towards various weak nucleophiles including water, amines and other very mild bases (Matoba et al, 1987). Also ptaquiloside must be capable of passing through the cell and nucleus membranes, as it brings about chromosomal aberration (Matsuoka et al, 1989) via irreversible damage to uncoiled DNA (Ojika et al, 1989).

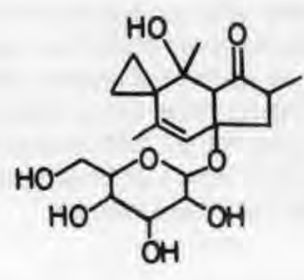

ptaquiloside

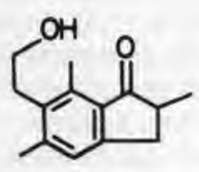

pterosin B
Fig 1. Structure of ptaquiloside and pterosin B. Structure du ptaquiloside et de la ptérosine $B$. 
On the other hand, various cancerous tumors have been induced in rats and mice given oral doses of milk obtained from cows fed with dietary complements of bracken fern (Evans et al, 1972; Pamukcu et al, 1978; Villalobos-Salazar et al, $1989 \mathrm{~b})$. Earlier results have also indicated that calves experienced lowered bone marrow activity when allowed to suck their bracken-fed mother cow's milk (Evans, 1986).

All this evidence points toward the presence of deleterious bracken metabolites in bovine milk. Some toxic compounds in animal feed such as aflatoxins and some pesticides have been known for some time either directly or after derivatization by body enzymes to pass into the milk in bovines. Bracken metabolites may be no exception. However, in spite of these advances, so far the chemical analysis of milk has been poor in providing direct evidence of secondary bracken compounds. It has been considered that to formally demonstrate the existence of a link between bracken and human cancer, the detection of the bracken carcinogen 1 in milk is required. It is the purpose of this paper to report on the first detection of ptaquiloside in milk from cattle exposed to bracken fern.

\section{MATERIALS AND METHODS}

\section{Milk extraction procedure}

The entire sequence was carried out at $36^{\circ} \mathrm{C}$ to increase the rate of protein and lipid precipitation. A milk sample (2 I) was warmed to $36^{\circ} \mathrm{C}$ and methanol ( $4 \mathrm{I}$ ) was added with stirring for 30 $\min \left(5 \mathrm{~h}\right.$ at $\left.36^{\circ} \mathrm{C}\right)$. The suspension was filtered through cheesecloth, then filter paper and finally centrifuged $(3000 \mathrm{rpm}, r=38 \mathrm{~cm})$. The supernatant was evaporated in vacuo at $36^{\circ} \mathrm{C}$ to 300 $\mathrm{ml}$ and acetonitrile (1 I) was added in portions while the deposited solids were gradually removed to prevent the formation of a sticky mass. The suspension was centrifuged, the volume of the liquid phase corrected to $300 \mathrm{ml}$ by evaporation at $36^{\circ} \mathrm{C}$, and $20 \mathrm{~g}$ sodium chloride was added. This solution was extracted successively with hexane $(3 \times 50 \mathrm{ml})$ and dichloromethane $(6 \times 25 \mathrm{ml})$ (extract A). To the aqueous layer was added $15 \mathrm{ml}$ of an aqueous sodium hydroxide $(0.003 \mathrm{~N})$ solution and allowed to stand at $36^{\circ} \mathrm{C}$ for $2 \mathrm{~h}$ with stirring. The mixture was then extracted with dichloromethane $(6 \times 25$ ml) (extract B) to draw out the pterosin B derived from ptaquiloside in the milk sample.

\section{Microcolumn prepurification}

The modified procedure of Alonso-Amelot et al (1992a) was used. Extracts $A$ and $B$ were submitted to the same protocol: the dichloromethane solutions were evaporated over silica gel $(100 \mathrm{mg})$ at room temperature in vacuo, and the solid residue was transferred to a microcolumn prepared from a Pasteur pipette filled with 300 $\mathrm{mg}$ silica gel $70-230$ mesh. The column was eluted with 1) $2.5 \mathrm{ml}$ hexane-ethyl acetate 9:1 and 2) $3.0 \mathrm{ml}$ hexane-ethyl acetate 1:4. Only the second fraction contained pterosin $\mathrm{B}$. This eluent was evaporated in a current of dry nitrogen gas, and redissolved in HPLC grade metha$\mathrm{nol}(2.0 \mathrm{ml})$.

\section{HPLC analysis}

A LDC Milton Roy HPLC apparatus composed of a Constametric II pump, a Rheodyne 20- $\mu$ l loop injector and a Waters $490 \mathrm{E}$ multichannel UV-VIS detector tuned at $260 \mathrm{~nm}$ connected to a radial $0.5 \times 10 \mathrm{~cm} \mathrm{C-18}$ column was used. The optimum separation conditions were as follows: solvent: methanol-water $65: 35$ in the isocratic mode, flow: $1.0 \mathrm{ml} / \mathrm{min}$, at room temperature. The pterosin B peak appeared at Rt $=10^{\prime} 10^{\prime \prime}$.

\section{Cow conditioning and milk sampling}

A 3-year old $100 \%$ Holstein female in its 4 th milking month was selected from a herd and maintained on a Kikuyu (Pennisetum clandestinum) plot (altitude $1900 \mathrm{~m}$ ) and commercial animal feed concentrate at a rate of $2 \mathrm{~kg}$ day. The 
positive health condition of the animal was monitored for 4 months before the bracken-feeding experiment was started. Freshly-cut bracken fronds $(6 \mathrm{~kg})$ were then administered orally in an admixture with fresh Kikuyu grass and molasses every morning for 7 consecutive $d$. After the morning milking was collected ( 24 I daily average), 2 I samples were separated and immediately taken to the laboratory for analysis as described above.

\section{RESULTS AND DISCUSSION}

Ptaquiloside is a very unstable compound. Once isolated from the plant it decomposes quickly into pterosin B under mild acid, base or heat (Saito et al, 1989). Any clean-up procedure used to detect this compound in milk must avoid these conditions in order to preserve its molecular integrity. In particular, commonly-used reagents for milk analysis such as acetic, sulfuric and hydrochloric acids must not be utilised. The direct analysis of ptaquiloside in a complex matrix such as milk is therefore not practical. Nevertheless, a milk prepurification sequence was designed to defat and deproteinise milk samples under neutral conditions. It was based on the precipitation of insoluble material via methanol and acetonitrile, followed by extraction with hexane and dichloromethane as described in figure 2 (see also the Materials and Methods section). The remaining aqueous phase was then analyzed by HPLC after silica gel microcolumn prepurification (Alonso-Amelot et al, 1992a). This strategy ensured that any pterosin B that was to be detected at this point would not come from ptaquiloside decomposition, but from the ingested bracken that contained pterosin B as a natural metabolite. Indeed, a ptaquiloside-enriched sample obtained from the purification of a water extract of bracken resisted the indicated milk precipitation and microcolumn prepurification scheme without apparent change.
Conversely, any pterosin B appearing in the liquid chromatograms of milk extracts treated with mild base after precipitation and solvent extraction should come exclusively from the decomposition of ptaquiloside. Another potential pterosin B precursor present in bracken is the pterosin glucoside pteroside $\mathrm{B}$. When an authentic sample of this compound was added to a milk sample which was then subjected to the purification sequence including the base treatment step at a higher temperature $\left(50^{\circ} \mathrm{C}\right)$, it remained totally unchanged and no detectable pterosin B was produced. This analytical strategy is depicted in figure 3.

The bovine specimens for milking were distributed into 2 groups. In the first group a herd of 4 Holstein cows were kept in a 2 . ha plot that was heavily infested with bracken growth. After 24 months 3 of the animals had developed enzootic hematuria. At their medium lactation period, milk samples were taken from the animals once a wk for 3 wk and analyzed for the contents of pterosin B naturally occurring in the fern, and for ptaquiloside via its base transformation into pterosin B following the analytical sequence described above. None of these samples showed signs of natural or induced pterosin B in the HPLC chromatograms down to a detection limit of $0.4 \mathrm{ng}$ per injection.

In the second group, one healthy 3year-old Holstein cow in her 4th month of lactation was given oral complements in the order of $6 \mathrm{~kg}$ fresh weight (850 g DM) of freshly-cut bracken fronds of intermediate growth (ca 40-50 days from emergence) every $24 \mathrm{~h}$ in addition to its normal Kikuyu grass diet and animal-feed concentrate. The ptaquiloside content of the fronds was estimated by HPLC (AlonsoAmelot et al, 1992b) to be $0.250 \pm 0.050$ $\mathrm{mg}$ per $\mathrm{g}$ vegetation biomass. This gave an average of $216 \mathrm{mg} / \mathrm{carcinogen} / \mathrm{d}$ added to the diet. This treatment was extended 


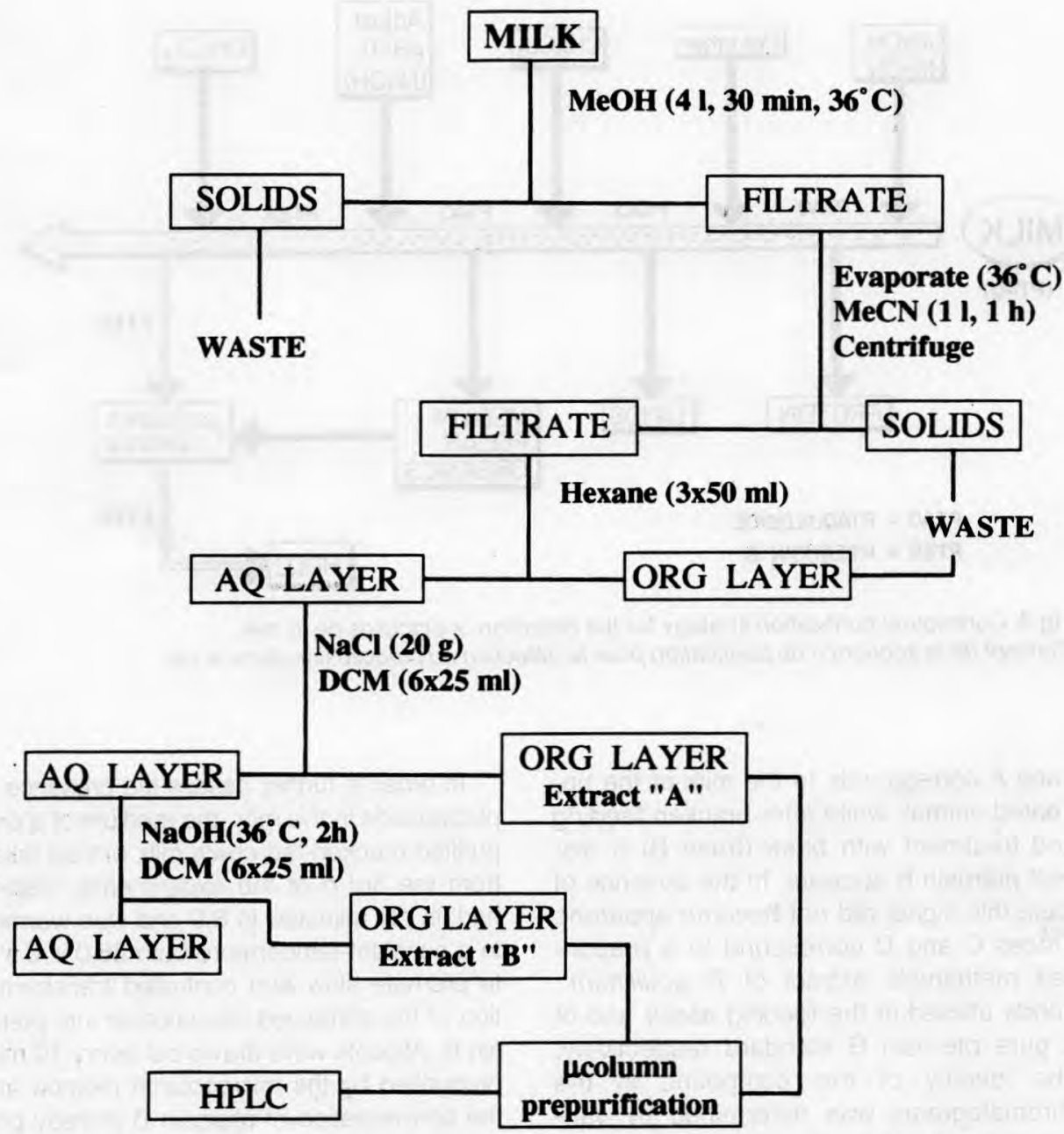

Fig 2. Milk purification sequence for the detection of ptaquiloside, the bracken fern carcinogen. Séquence de purification pour la détection du ptaquiloside, le carcinogène de la fougère.

for 7 consecutive $d$ and then discontinued. Milk samples were taken daily in the early morning and $7 \mathrm{~d}$ after the bracken treatment had been ceased. During the treatment there was no net reduction of the average volume of milk produced $(24 \mathrm{l} / \mathrm{d})$, nor was there any indication of sickness or disturbance in the animal. Hence the amounts of bracken metabolites administered were under the toxicity level (as yet undetermined) of the cow in question.

All the milk samples from this animal that were taken after the first $48 \mathrm{~h}$ of bracken feeding did not contain any detectable natural pterosin, but the extracts treated with mild base at $\mathrm{pH} 11.5$ showed a distinct pterosin B peak in the liquid chromatograms. This is shown in figure 4 where 


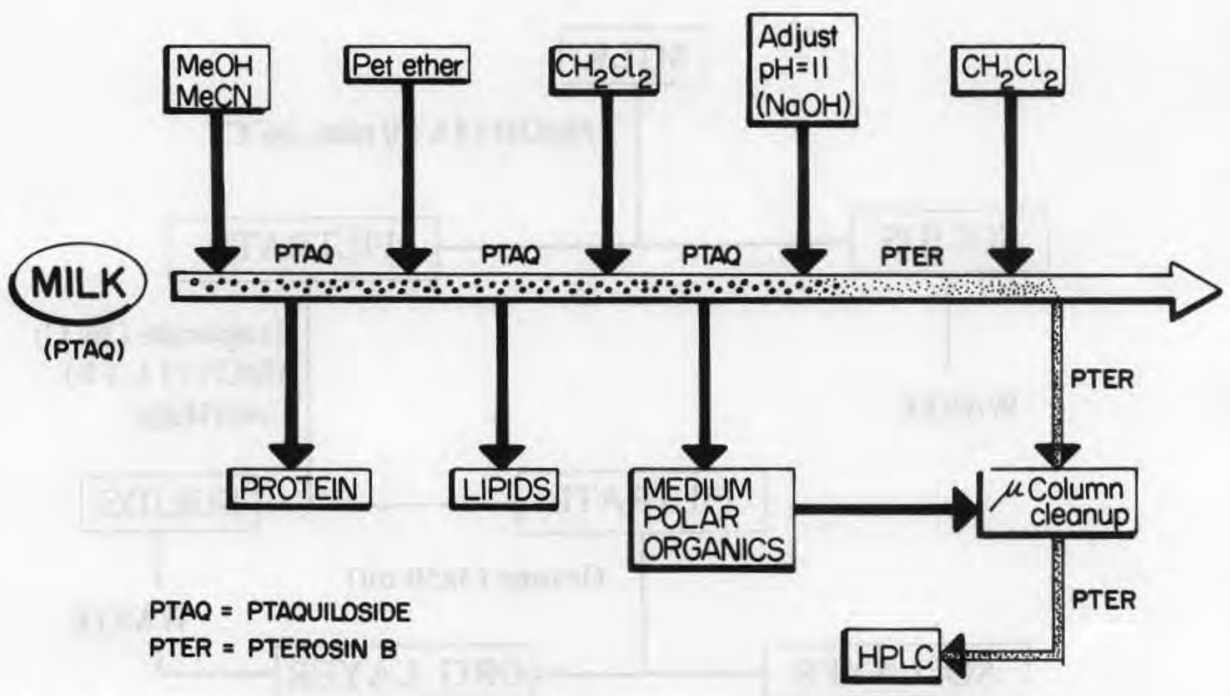

Fig 3. Conceptual purification strategy for the detection of ptaquiloside in milk. Concept de la séquence de purification pour la détection du ptaquiloside dans le lait.

trace A corresponds to the milk of the untreated animal, while after bracken feeding and treatment with base (trace B) a distinct pterosin B appears. In the absence of base this signal did not become apparent. Traces $\mathrm{C}$ and $\mathrm{D}$ correspond to a prepurified methanolic extract of $P$ aquilinum fronds utilised in the feeding assay and of a pure pterosin B standard respectively. The identity of this compound in the chromatograms was determined by various methods, including comparison of retention times, co-injection and peak enrichment with pterosin B standards. In addition, the UV spectrum of this peak obtained with the aid of the multichannel spectrophotometric detector employed was identical to that of an authentic sample, as illustrated in figure 5 . It is clear that the only way for pterosin B to appear after the base treatment of the milk extract must have been the base-induced decomposition of ptaquiloside originally present in the milk.
In order to further assess the presence of ptaquiloside in the milk, the medium of a prepurified bracken-fed cow's milk extract taken from the $3 \mathrm{rd} \mathrm{d}$ of the experimental feeding had its $\mathrm{pH}$ adjusted to 8.0 and was warmed in a constant-temperature bath $38.0 \pm 0.5^{\circ} \mathrm{C}$ to promote slow and controlled transformation of the contained ptaquiloside into ptero$\sin$ B. Aliquots were drawn out every $10 \mathrm{~min}$, prepurified by the microcolumn method and the concentration of pterosin B thereby produced determined by HPLC. The ptaquiloside-pterosin conversion was assessed by following the height of the pterosin B peak. It was found to increase smoothly and asymptomatically to completion during the first 60 min of warming. A parallel experiment using a ptaquiloside-enriched milk sample under the same $\mathrm{pH}$ and temperature conditions, displayed a similar behaviour was observed, as shown by the data in figure 6 . Hence the hypothesis that ptaquiloside was present in the milk of the bracken-fed cow was fully demonstrated. 
That the herd of 4 cows exposed to voluntary feeding of bracken fern did not show signs of ptaquiloside in the milk can be explained on 2 grounds. First, although it was clear that the animals did in fact eat limited amounts of fern since they developed enzootic hematuria only attributable to fern intoxication, their feeding on this plant may have been only casual or under stress when other grasses became scarce. Therefore, the concentration of ptaquilo-

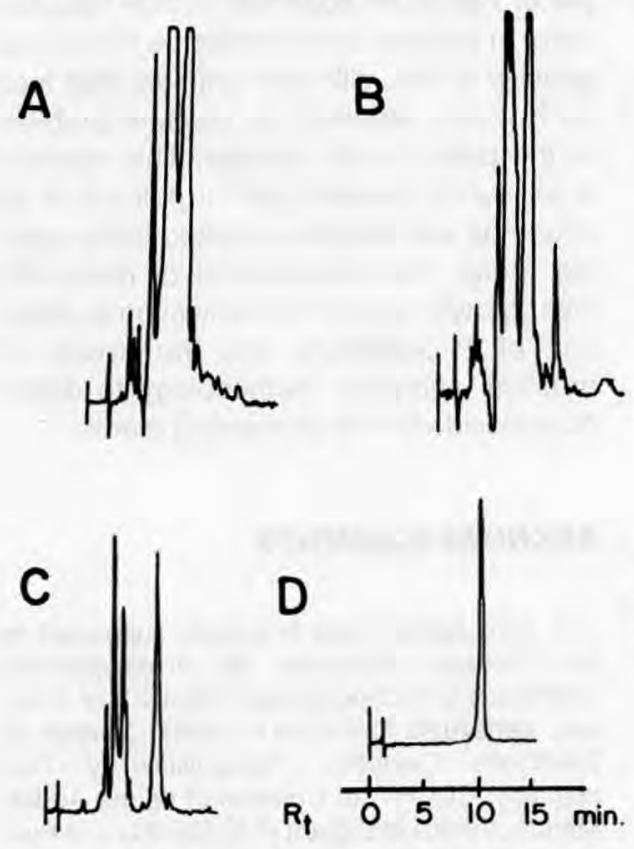

Fig 4. HPLC chromatograms of milk and bracken frond fractions: A) milk extract A. B) Milk fraction treated with dilute base (extract $B$ ) showing a distinct pterosin B peak. C) Waterdichloromethane extract of bracken fronds used for the feeding experiment. D) Pterosin B standard. For specific HPLC conditions see text. Chromatogrammes de HPLC des fractions de lait et frondes de fougère. A) Extrait $A$ du lait. B) Fraction du lait traité avec une base diluée (extrait B) qui montre clairement un pic de ptérosine B. C) Extrait d'eau-dichlorométhane des frondes de fougère utilisées dans l'expérience de l'alimentation. D) Standard de ptérosine B. Pour les conditions spécifiques de HPLC, voir le texte. side excreted through their milk may have been minimal, possibly under the detection limit of the present method. Second, in the voluntary feeding situation there was no precise record of the last time that the cows had actually eaten bracken. It could well be that, ptaquiloside being an unstable chemical, its mean residence time in the rumen could be short, particularly under the rather high temperatures of the rumen mass $\left(40-42^{\circ} \mathrm{C}\right)$. In fact, a milk sample from the bracken-force-fed cow obtained $7 \mathrm{~d}$ after the last meal including bracken did not show any detectable ptaquiloside-derived pterosin B in the extracts. Hence, animals exposed to bracken

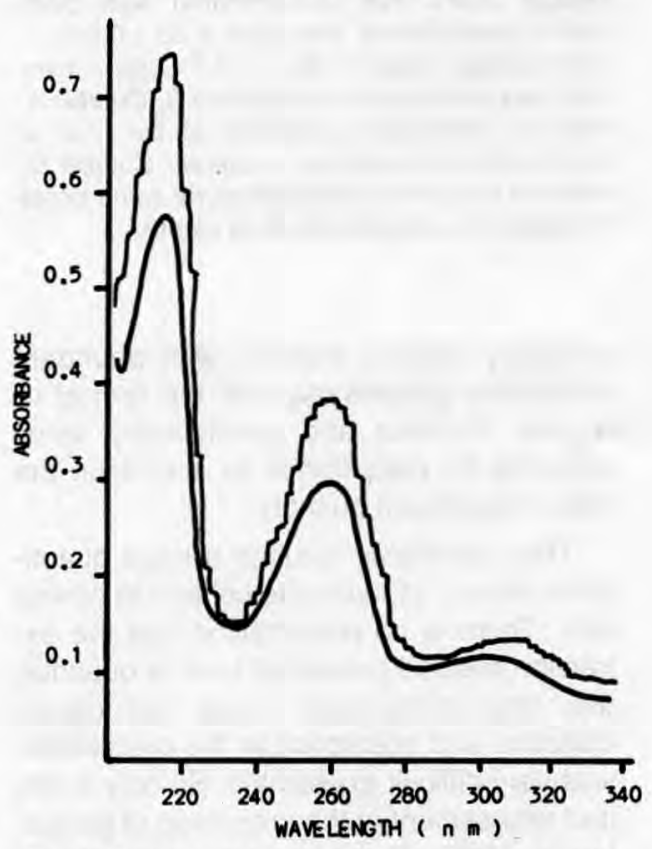

Fig 5. Comparison of the UV spectra of pterosin B peak obtained in the HPLC trace after base treatment. Solid line: spectrum of pterosin standard. Broken line: spectrum of HPLC peak attributed to pterosin B.

Comparaison des spectres UV du pic de ptérosine B obtenu par HPLC après traitement alcalin. Trait continu: spectre de ptérosine standard. Trait pointillé : spectre du pic de HPLC attribué à la ptérosine $B$. 


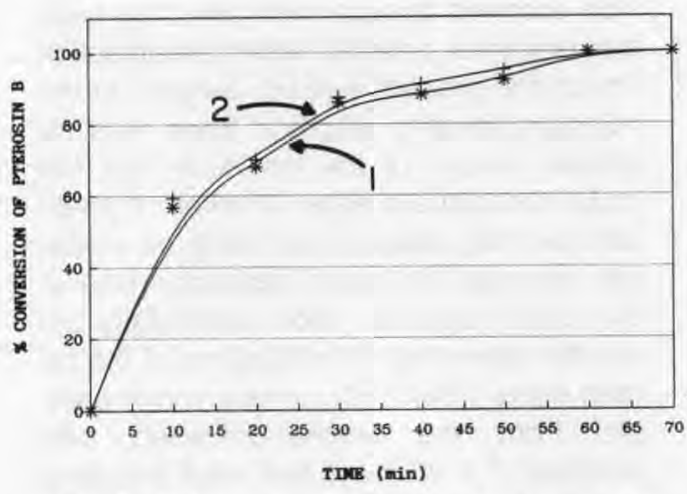

Fig 6. Relative \% conversion of ptaquiloside into pterosin B. Curve (1): in a prepurified milk sample of a bracken-fed bovine. Curve (2): in a healthy cow's milk contaminated with plantderived ptaquiloside. Both runs at $38 \pm 0.5^{\circ} \mathrm{C}$. Pourcentage relatif a $38,0 \pm 0,5^{\circ} \mathrm{C}$ de conversion de ptaquiloside en ptérosine $B$. Courbe $A$ : dans un échantillon prépurifié de lait chez un bovin alimenté avec des fougères. Courbe $B$ : dans un lait provenant d'une vache saine contaminé avec le ptaquiloside de la plante.

voluntary feeding together with abundant alternative grasses may eat the fern at irregular intervals and insufficiently small amounts for ptaquiloside to appear in the milk in significant quantity.

This hypothesis required a more quantitative view of ptaquiloside content in bovine milk. There is no presumption that the extraction method presented here is quantitative, since ptaquiloside losses from coprecipitation and adsorption in the precipitates was very difficult to estimate. So only a limited assessment of the proportion of ptaquiloside relative to the ingested material can be advanced at this time. The concentrations of observed pterosin B were calculated against a calibration curve by standard procedures. When these values were translated in terms of ptaquiloside, it was found to be no less than $0.11 \mathrm{mg} / \mathrm{l}$ fresh milk. In terms of the $24 \mathrm{l} / \mathrm{d}$ produced by the test ani$\mathrm{mal}$, this becomes $2.60 \mathrm{mg} / \mathrm{d}$ ptaquiloside excreted into the milk, which represents $\approx 1.2 \%$ of the total ingested carcinogen.

\section{CONCLUSIONS}

The exposure of dairy cattle to bracken fern is not only of economic concern owing to disease and death of livestock, but the discovery of the potent carcinogenic principle of Pteridium aquilinum in milk reported here, in addition to the evidence of carcinogenicity of the milk from animals that feed on bracken, extends the bracken problem to the public health domain. This requires a review of bracken control policies in all countries with bracken-infested cattle grazing areas, the development of more efficient growth control or eradication technology of $P$ aquilinum, and the design of practical analytical methodology to detect ptaquiloside in milk processing plants.

\section{ACKNOWLEDGMENTS}

This investigation was financially supported by the Consejo Nacional de Investigaciones Cientificas y Technológicas, CONICIT of Caracas, Venezuela (grant No PC-064), Consejo de Desarrollo Científico, Humanistico y Tecnológico, CDCHT, of Universitad de los Andes, Mérida, Venezuela (grant $n^{\circ} \mathrm{C}-526-91$ ) and Fundación Polar of Caracas, Venezuela.

\section{REFERENCES}

Alonso-Amelot ME, Pérez-Mena $M$, Calcagno MP, Jaimes-Espinoza R (1992a) Quantitation of pterosins $A$ and $B$, and ptaquiloside, the main carcinogen of Pteridium aquilinum (L Kuhn), by high pressure liquid chromatography. Phytochem Anal 3, 160-164

Alonso-Amelot ME, Pérez-Mena M, Calcagno MP, Jaimes-Espinoza R, Castillo U (1992b) Ontogenic variation of biologically active metabolites of Pteridium aquilinum (L Kuhn), 
pterosins $A$ and $B$, and ptaquiloside in a bracken population of the tropical Andes. $J$ Chem Ecol 18, 1405-1420

Barnett KC, Watson WA (1970) Bright blindness in sheep. A primary retinopathy due to feeding bracken (Pteris aquilina). Res Vet $\mathrm{Sci} 2$, 289-291

Cooper-Driver GA, Swain T (1976) Cyanogenic polymorphism in bracken in relation to herbivore predation. Nature (Lond) 260, 604-605

Diniz JMF, Basile JR, de Camargo NJ (1984) IntoxicaÇao natural de asininos por Pteridium aquilinum (L Kuhn) no Brasil. Arq Bras Med Vet Zoot 36, 515-522

Evans IA, Widdop B, Jones RS, Barber GD, Leach $H$ (1971) Possible human hazard of the naturally occurring bracken carcinogen. Biochem J 124, 28-32

Evans IA, Jones RS, Mainwaring-Burton R (1972) Passage of bracken fern toxicity into milk. Nature (Lond) 237, 107-108

Evans WC (1976) Bracken thiaminase-mediated neurotoxic syndromes. Bot $J$ Linn Soc 73 , 113-131

Evans WC (1986) The acute diseases caused by bracken in animals. In: Bracken, Ecology, Land Use and Control Technology (Smith RT, Taylor JA, eds) Parthenon Publ Group, Carnford, Lancashire, UK, 121-132

Evans WC, Widdop B, Harding JDJ (1972) Experimental poisoning by bracken rhizomes in pigs. Vet Rec $90,471-475$

Fenwick GR (1988) Bracken (Pteridium aquilinum). Toxic effects and toxic constituents. J Sci Food Agric 46, 147-173

Fletcher WW, Kirkwood RC (1979) The bracken fern Pteridium aquilinum (L Kuhn). Its biology and control. In: The Experimental Biology of Ferns (Dyer AF, ed) Academic Press, London

Fukuoka M (1982) Chemical and toxicological studies on bracken fern, Pteridium aquilinum var latiusculum. VI. Isolation of 5-0-caffeoyl shikimic acid as an antithiamine factor. Chem Pharm Bull 30 3219-3224

Galpin OP, Smith RMM (1986) Bracken, stomach cancer and water supplies: is there a link? In: Bracken, Ecology, Land Use and Control Technology (Smith RT, Taylor JA, eds) Parthenon Publ, Carnforth, UK, 149-157
Gliessman SR (1978) The establishment of bracken following fire in the tropical habitats. Am Fern J 68, 41-44

Harding JDJ (1972) Bracken poisoning in pigs. Agriculture 9, 313-314

Harper JL (1977) Population Biology of Plants. Academic Press, London

Hirono I, Ogino H, Fujimoto M, Yamada K, Yoshida $Y$, Ikagawa $M$, Okumura $M$ (1987) Induction of tumors in $\mathrm{ACl}$ rats given a diet containing ptaquiloside, a bracken carcinogen. J Natl Cancer Res Inst 79, 1143-1149

Hodge WH (1973) Fern food of Japan and the problem of toxicity. Am Fern J 63, 77-80

Matoba M, Saito E, Saito MK, Koyama K, Natori S, Matsushima T, Nakimoto M (1987) Assay of ptaquiloside, the carcinogenic principle of Pteridium aquilinum by mutagenicity testing in Salmonella typhimurium. Mutagenesis 2, 419-423

Matsuoka A, Hirosawa A, Natori S, Iwasaki S, Sofuni T, Ishidate Jr M (1989) Mutagenicity of ptaquiloside, the carcinogen in bracken and its related illudane-type sesquiterpenes. II. Chromosomal aberration tests with cultured mammalian cells. Mutat Res 215, 179185

McCleary BV, Chick BF (1977) The purification and properties of a thiaminase I enzyme from nardoo (Marsilea drummondii). Phytochemistry 16, 207-213

Niwa H, Ojika M, Wakamatsu K, Yamada K, Hirono I, Matsushita K (1983) Ptaquiloside, a novel norsesquiterpene glucoside from bracken Pteridium aquilinum var latiusculum. Tetrahedron Lett 24, 4117-4120

Ojika M, Sugimoto K, Okazaki T, Yamada K (1979) Modification and cleavage of DNA by ptaquiloside. A new potent carcinogen isolated from bracken fern. $J$ Chem Soc Chem Commun 1775

Ortega $F$ (1990) El género Pteridium en Venezuela: taxonomía y distribución geográfica. Biollania 7, 47-56

Page CN (1976) The taxonomy and phytogeography of bracken. A review. Bot J Linn Soc $73,1-34$

Page CN (1982) The history and spread of bracken in Britain. Proc $R$ Soc Edinburgh 81B, 3-10 
Pamukcu AM, Erturk E, Yalciner S, Milli U, Bryan GT (1978) Carcinogenic and mutagenic activities of milk from cows fed bracken fern (Pteridium aquilinum). Cancer Res 38, 1556- 1660

Philp RG, Gowdey CW (1967) Anemia, thrombocytopenia and reduced platelet adhesiveness in rats fed Pteridium aquilinum. Nature (Lond) 216, 498-499

Rosenberger G (1971) Nature, manifestations, cause and control of chronic enzootic hematuria in cattle. Vet Med Rev 71, 189-206

Saito K, Umeda M, Enomoto M, Hatanaka $T$, Nator S, Yoshihira K, Fukuoka M, Kuroyanagi M (1975) Cytotoxicity and carcinogenicity of pterosins and pterosides. 1. Indanone derivatives from bracken fern (Pteridium aquilinum). Experientia (Basel) 31, 829-831

Saito K, Nagoa T, Matoba M, Koyama K, Natori S, Murakami T, Saiki Y (1989) Chemical assay of ptaquiloside, the carcinogen of Pteridium aquilinum, and the distribution of related compounds in the pteridiaceae. Phytochemistry 28, 1605-1611

Saito T, Kurata Y, Takeno K (1990) Characteristics of histamine release from rats mast cells by a bracken toxin, braxin 1A. Jpn J Pharmacol 53, 165-173

Tryon RM (1941) A revision of the genus Pteridium. Rhodora 43, 1-31
Van Der Hoeven JCM, Lagenweij WJ, Posthumus MA, van Veldhuizen A, Holterman HAJ (1983) Aquilide, a new mutagenic compound isolated from bracken fern (Pteridium aquilinum L Kuhn). Carcinogenesis 4, 1587-1590

Villalobos-Salazar J (1985) Carcinogenicidad del Pteridium aquilinum y alta ncidencia del cáncer gástrico en Costa Rica. Rev Costarric Cienc Med 6, 131-139

Villalobos-Salazar J (1987) Pteridium aquilinum and gastric cancer. Abstr XXIII World Vet Congr, August 15, Montreal, Canada, p 90

Villalobos-Salazar J, Meneses A, Rojas JL, Mora J, Porras RE, Herrero MV (1989a) Bracken derived carcinogens as affecting animal and human health in Costa Rica. In: Bracken Toxicity and Carcinogenicity as Related to Animal and Human Health (Taylor JA, ed). Spec Publ Int Bracken Group, Geography Dep, Univ College N Wales, Aberystwyth, Wales, UK, p 40

Villalobos-Salazar J, Meneses A, Salas J (1989b) Carcinogenic effects in mice of milk from cows fed on bracken fern Pteridium aquilinum. In: Bracken, Biology and Management (Thompson JA, Smith RT, eds) Inst Agric Sci, Occ Publ No 40, Sydney, Australie, p 247 